\title{
Erratum to: Comparative Analysis of the Protective Effects of Caffeic Acid Phenethyl Ester (CAPE) on Pulmonary Contusion Lung Oxidative Stress and Serum Copper and Zinc Levels in Experimental Rat Model
}

\author{
Mehmet Sirmalı • Okan Solak • Cagatay Tezel • \\ Rana Sirmalı • Zeynep Ginis • Dilek Atik • \\ Yetkin Agackıran • Halis Koylu • Namık Delibas
}

Published online: 5 December 2012

(C) Springer Science+Business Media New York 2012

\section{Erratum to: Biol Trace Elem Res}

$$
\text { DOI 10.1007/s12011-012-9505-7 }
$$

The original version of this article unfortunately contained mistakes. On the Materials and Methods of the above mentioned article, the number of subjects listed for each group is incorrect. The correct numbers are: Group $1(n=9)$; Group 2 $(n=9)$; Group $3(n=36)$ and Group $4(n=27)$. We apologize for the mistake.

The online version of the original article can be found at http:// dx.doi.org/10.1007/s12011-012-9505-7.

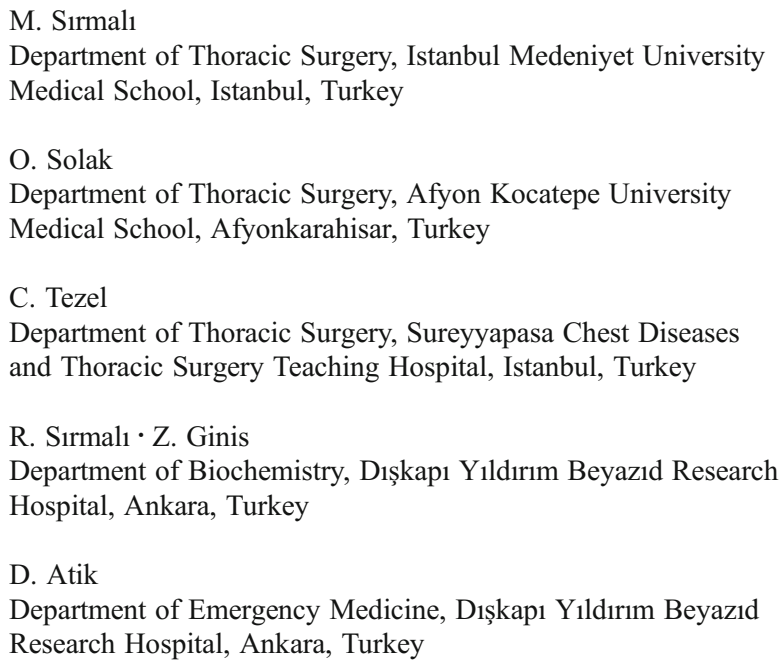

Y. Agackıran

Department of Pathology, Ataturk Chest Diseases and Thoracic Surgery Research Hospital, Ankara, Turkey

H. Koylu

Department of Physiology, Süleyman Demirel University Medical School, Isparta, Turkey

N. Delibas

Department of Biochemistry, Bozok University Medical School, Yozgat, Turkey

M. Sirmalı $(\bowtie)$

Department of Thoracic Surgery, Istanbul Medeniyet University Medical School and Süreyyapaşa Göğüs Hastalıkları ve Göğüs Cerrahisi Eğitim ve Araştırma Hastanesi D blok Başıüyü̈k Maltepe, Istanbul, Turkey

e-mail: mehmet_sirmali@yahoo.com 